\title{
Glutamate and post-traumatic cerebral excitoxicity as possible therapeutic targets - A literature review
}

José Luís Alves ${ }^{1}$, Anabela Mota Pinto²

Laboratório de Patologia Geral, Faculdade de Medicina da Universidade de Coimbra.

\section{ABSTRACT}

Cerebral edema and excitoxicity are well known phenomena and are reported in multiple pathological contexts. Despite that, regarding traumatic brain injury, significant events in incidence and potential clinical consequences, little is known about the actual promoting and modulating processes of cerebral damage, namely in relation to glutamate, the main excitatory endogenous neurotransmitter of the central nervous system. Based on current concepts on neuropathology and cerebral regulation, a thorough review is made on the glutamatergic regulation system, its role and mechanisms of action in a secondary response to TBI, namely in cortex and hippocampus, sensible areas to acute and delayed damage. Current and past clinical trials are also mentioned as attempts to modulate these events, with no clinical significance so far. A better knowledge of the glutamatergic deregulation and related excitoxicity should play a key role in the understanding of TBI and provide a basis for possible therapeutic targets in a close future.

\section{KEYWORDS}

Glutamic acid, receptors $N$-methyl-D-aspartate, craniocerebral trauma.

\section{RESUMO}

Glutamato e excitotoxicidade cerebral pós-traumática como possíveis alvos terapêuticos Revisão da literatura

O edema cerebral e a excitotoxicidade são fenômenos bem conhecidos e foram descritos em múltiplos contextos patológicos. Apesar disso, em relação ao traumatismo cranioencefálico (TCE), acontecimento significativo em termos de incidência e consequências clínicas, pouco se sabe acerca dos reais processos de promoção e modulação do dano cerebral, nomeadamente em relação ao glutamato, o principal neurotransmissor excitatório endógeno do sistema nervoso central. Baseando-se em conceitos atuais de Neuropatologia e regulação cerebral, é feita uma revisão do sistema de regulação glutamatérgico, o seu papel e mecanismos de ação na resposta secundária ao TCE, nomeadamente no córtex e hipocampo, áreas propensas ao dano imediato e tardio. São referidos os diferentes ensaios clínicos até a data, como tentativas de modulação desses eventos, sem significância clínica até ao momento. Um melhor conhecimento da desregulação glutamatérgica e concomitante excitotoxicidade deverá desempenhar papel crucial na compreensão do TCE e funcionar como ponto de partida para eventuais alvos terapêuticos no futuro.

\section{PALAVRAS-CHAVE}

Ácido glutâmico, receptores de N-metil-D-aspartato, traumatismos craniocerebrais.

1 Student of Doctoral Program, Faculdade de Medicina da Universidade de Coimbra, Portugal.

2 Professor of Pathophysiology, Faculdade de Medicina da Universidade de Coimbra, Portugal. 


\section{Introduction}

Traumatic brain injury (TBI) is a common clinical condition, one of the most frequent traumatic situations in the pediatric and adult ages, necessarily unforeseen and sudden in progress, with multiple causes (traffic accidents, falls, gunshot wounds) and possibly devastating consequences for the victim and a huge burden for the society, implying huge costs in public health care. Previous reports on humans ${ }^{1,2}$ and animal models ${ }^{3,4}$ have shown, along with major neurological deficits/ symptoms (motor deficits, epilepsy), the persistence of unspecific complaints (namely headaches) and minor cognitive deficits - affected spatial orientation and memory, diminished learning abilities and work performance - directly related to neuronal hippocampal loss. ${ }^{3,5,6}$ These symptoms, obvious after $48 \mathrm{~h}$, can persist over two weeks (postconcussion syndrome) and even become permanent. ${ }^{7}$ It has also been associated with an increased risk for Depression ${ }^{8}$ or neurodegenerative diseases. ${ }^{9}$ Emotional processing disturbances can also be attributed to hippocampal damage, according to recent theories on cognitive/mnesic mechanisms and complex emotional states..$^{10} \mathrm{TBI}$ is the cause of death in $30 \%-50 \%$ of all deaths related to traumatic events, ${ }^{11,12}$ with a mortality rate of $18,1 / 100.000$ inhabitants (period 1995-2001), according to CDC (Centers for Disease Control, TBI Surveillance System $)^{13}$ (official sources). Even in low-energy trauma, representing $70 \%$ to $90 \%$ of all TBI's, ${ }^{13}$ the risk for complications or progression of initial injury or cerebral edema poses a significant challenge for the neurosurgeon/neurointensivist. Despite the technology and medical care nowadays increasingly available, it is constantly reminded the need for further tools, capable of guiding the decision process and monitoring, and new therapeutic strategies, effective against self-sustained pathological processes.

\section{Discussion}

In TBI, one can distinguish the initial primary events of cellular damage and consequent neurological deficit, including intra-cranial bleeding or cerebral contusions as major primary lesions, and secondary mechanisms of loco-regional, cellular and biochemical deregulation - increased vascular permeability, vascular dilatation, ionic exchanges deregulation - leading to cerebral edema and cellular death (Figure 1). These secondary pathological events, multifactorial in their nature, progress for days after the initial traumatic event and are theoretically subject to pharmacological intervention. It should be mentioned that, although most reports focus on neuronal damage, the concept of astrocyte and glial cell damage is gaining importance, as shown in recent reports, ${ }^{14-17}$ with parallel mechanisms of aggression. ${ }^{18-20}$

Clinical and animal-model studies with microdialysis $^{21-25}$ and spectroscopy ${ }^{27}$ (regarding pediatric ages) have shown a significant post-traumatic increase in extracellular levels of glutamate (Figure 2), the main excitatory endogenous neurotransmitter of central nervous system, as well as of lactate (from anaerobic glicolysis $)^{27}$ and aspartate. ${ }^{28}$ This was also shown in studies of cerebral spinal fluid from TBI victims. ${ }^{29,30}$ It should be mentioned that this increase is notorious as early as 6 hours after the trauma ${ }^{27}$ but only reaches its peak only around $48 \mathrm{~h},{ }^{24}$ proving this is not a merely acute event. This increase, described in many hypoxicischemic situations in relation to apoptosis/necrosis ${ }^{31}$

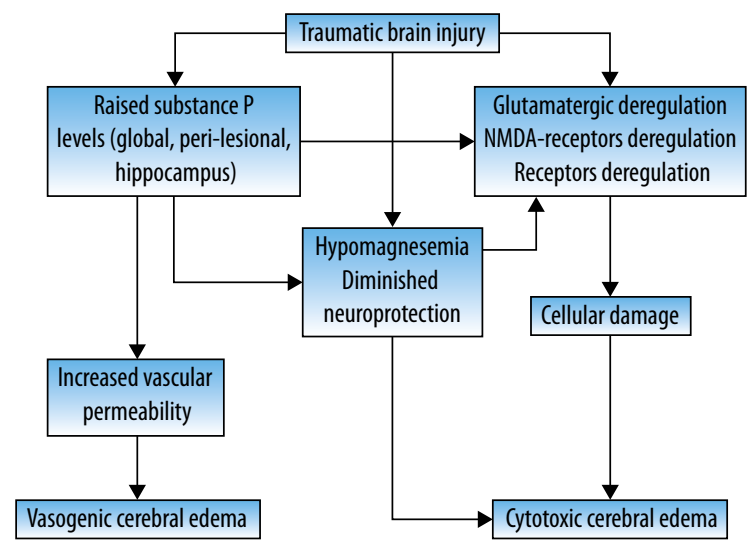

Figure 1 - Acute post-traumatic response and cerebral edema.

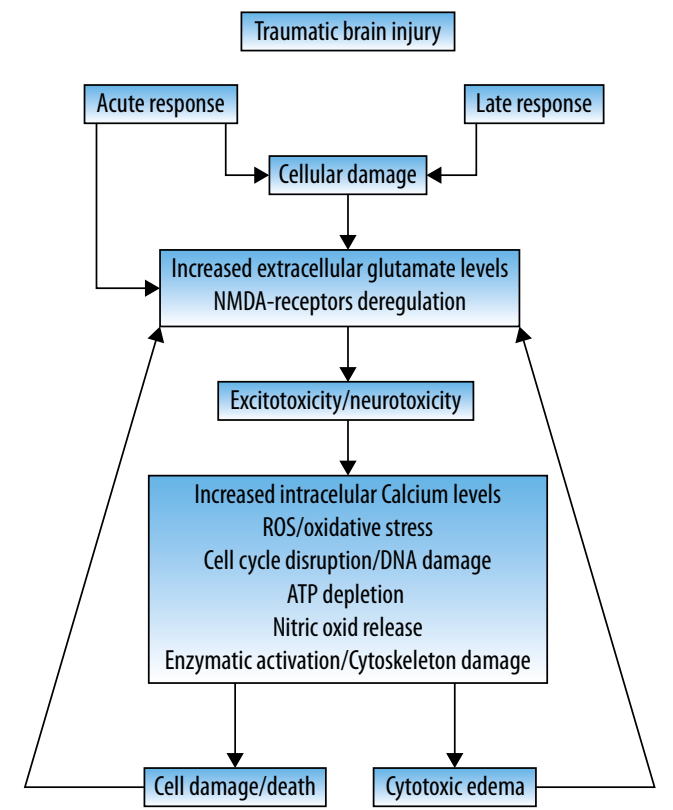

Figure 2 - Glutamatergic response in post-traumatic damage. 
is attenuated or abolished by induction of barbituric coma, ${ }^{28}$ which could explain the relative therapeutic role of this last-resort procedure. The levels of extracellular glutamate are regulated by astrocytic transporters GLAST (EAAT1) e GLT-1 (EAAT2), ,2-34 downregulating the excitoxic status. ${ }^{35,36}$ This pathological process leads to damage and cellular death, upon activation of ionotropic receptors NMDA or AMPA - type. More specifically, the activation of these receptors induces disruption of the homeostatic ionic balance, increasing intra-cellular levels of calcium ion $(\mathrm{Ca} 2+)$, in relation, among other mechanisms, with the high sodium ion $(\mathrm{Na}+)$ concentration - revision by Floyd et al. ${ }^{15}$ and others ${ }^{37,38}$ and inversion of the $\mathrm{Na}+\mathrm{Ca} 2+$ exchange system (sodiumcalcium exchanger, NCX) ${ }^{39}$ In this way, innumerous enzymatic complexes are activated (phospholipases, endonucleases, proteases), leading to cytoskeleton damage. Other studies, using glutamate-sensitive astrocytic cell cultures ${ }^{40}$ subject to mechanical trauma, have shown diminished intracellular $\mathrm{Na}+$ levels and improved cellular survival upon glutamate transport inhibition by TBOA (DL-treo-beta-benziloxiaspartate). ${ }^{15}$ This upset in $\mathrm{Ca} 2+$ metabolism, although acute, can last in time, as shown in studies proving delayed changes in $\mathrm{Ca} 2+$ homeostasis (30 days after the initial trauma), with rather unknown underlying mechanisms, in possible relation to clinical findings like post-traumatic seizures. ${ }^{38}$ Adding to this, following initial cell injury, one can also observe mitochondrial damage and release of oxygen reactive species (ROS), promoting apoptosis, documented in TBI animal models from $2 \mathrm{~h}$ to two weeks after the initial trauma. ${ }^{41}$ The increase in ROS release in an ischemic event, as a starting point for oxidative stress, is apparently the result of high extracellular glutamate levels. ${ }^{35,42,43}$ ROS are responsible for abnormal protein turnover, upsetting its normal function and interfering with cellular cycles, damaging DNA (breaks in chain or changes in the nucleotides components) (Figure 2). Different studies addressing the use of antioxidant agents in ischemic events failed to show encouraging results. ${ }^{43}$ Cell's structural damage eventually will imply inversion of the normal function of glutamate receptors, on a neuronal and astrocytic level, in part due to ATP depletion as a result of iNOS-mediated (inducible nitric oxide synthase $)^{44,45}$ nitric oxide release, with additional glutamate release to the extracellular compartment. ${ }^{46,47}$ Cellular damage, diminished glutamate uptake by sodium-dependent carriers, ${ }^{39}$ augmented extracellular/synaptic levels of glutamate, they all contribute to increased cell injury or death, which will then result in reduced glutamate uptake and its increased spilling, promoting a self-sustained process of neuronal/ astrocytic aggression (Figure 2) (vicious circle) $)^{18,48,49}$, documented in several clinical contexts: TBI, medullary lesions, ischemic events, neurodegenerative diseases. ${ }^{24,50-52}$ These increasingly disseminated events, promoting secondary damage, are in part responsible for the pathological changes in structures topographically distant from the initial trauma (e.g. contra-lateral hippocampus), being a potential therapeutic target in an attempt to stop or attenuate the phenomena leading to secondary, possibly permanent, damage (Figure 3 ). The pre-synaptic deregulation might itself be related to circuit alterations ${ }^{49}$ leading to behavioral changes and stimulus hypersensitivity, shown in animal models and humans victims of TBI.

Along with the frequent cortical contusion (or similar injury) and white matter tracts ultra-structural damage ${ }^{53}$ several experimental studies on TBI show significant damage to the ipsi and contra-lateral hippocampus ${ }^{54-56}$ including neuronal disruption on layer CA3 (up to $60 \%$ in the first $48 \mathrm{~h}^{55}$ and deafferentation in the CA1 layer. Immunohystochemical assays GFAP and Fluor-Jade staining - confirm neuronal and astrocytic structural damage, namely in the layers previously mentioned - CA1 and CA 3 - in the first $24 \mathrm{~h}$ after TBI. ${ }^{39}$ However, hippocampal damage is also observed in cell populations that, although not on necrosis/apoptosis processes, present several minor structural damages, including synaptic and dendritic degeneration, with diminished local synaptic density. ${ }^{57}$ In animal models of repetitive minor TBI, disperse gliosis and minimal changes in the deeper layers were shown. ${ }^{58}$ In several experimental models of posttraumatic hippocampal apoptotic phenomena, two distinct stages are obvious: an initial one - cellular damage and loss, followed by a progressive neuronal loss, persisting for days or even weeks ${ }^{59,60}$ (Figure 3). Hippocampal neuronal loss, as well as lower threshold for excitability, is obvious bilaterally but only really persisting ( 30 days) on the same side of the impact. ${ }^{61}$ Pyramidal CA3-layer and dentate gyrus hippocampal neurons appear to be most vulnerable to this bilateral degeneration ${ }^{59}$ following unilateral trauma, as a result of systemic repercussion of an initially localized event. The most frequent post-TBI cognitive impairment, memory disturbance, as well as spatial learning, can therefore be explained on anatomic-pathological grounds, regarding structural disruption, disturbance of neurometabolic equilibrium (documented in concussion-victims athletes submitted to MRI-spectroscopy ${ }^{62}$ and interference with normal hippocampal synaptic transmission, ${ }^{63,64}$ including raised excitability potential ${ }^{65} 48 \mathrm{~h}$ after TBI.

Hippocampal damage is amplified, as expected, with low doses of keinate receptor agonists, glutamate analogues. ${ }^{66}$ This can explain the neuroprotective effect, in animal models, of NMDA and AMPA-receptor antagonists ${ }^{67}$ facing an initial hypoxic-ischemic aggression, ${ }^{48}$ manifested by diminished cortical and hip- 
pocampal (mostly CA1 layer) neuronal loss. However, as with every clinical trials with neuroprotective agents in trauma, tests with Selfotel (CGS-19755) or Traxoprodil (CP-101606), NMDA-receptors antagonists, failed to show any improvement in morbidity and/or mortality. ${ }^{68-70}$ Other therapeutic targets were tested in animal models, including neuropeptide Substance P, a modulator for Glutamate levels and NMDA receptors, using Neurokinin antagonists and cannabinoid receptors type 2 antagonists, with promising results regarding functional outcome. ${ }^{71-75}$

The transition from animal experimental models to large prospective clinical trials has failed showing significant efficacy for these therapeutic agents, and none is included in the diverse daily-practice clinical protocols. Many reasons have been pointed for this: insufficient knowledge on pathophysiology, unknown optimal dosages and therapeutic timings, incorrect pharmacological preparation, arguable end-points, basic anatomical and physiological differences between human and animal models of disease ${ }^{76}$ among many others.

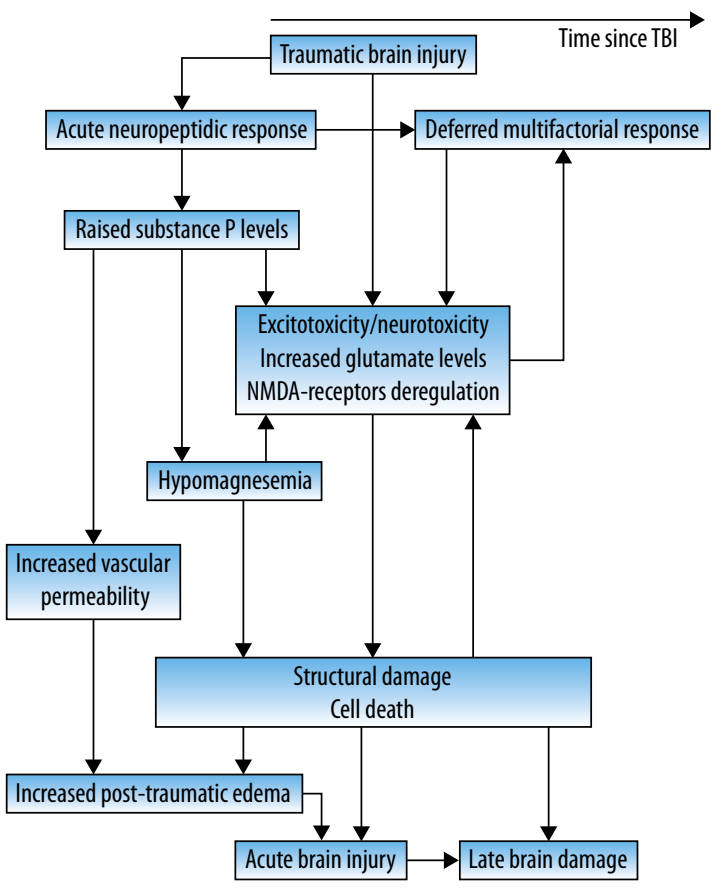

Figure 3 - Glutamatergic excitoxicity in post-traumatic damage.

\section{Conclusion}

With a multidisciplinary effort and profound knowledge of all the complex regulation systems involved, new specific therapies should be expected, capable of actively modulate the glutamatergic system and effectively play a role in diminishing morbidity and mortality in TBI.

\section{Author disclosure statement}

No competing financial interests exist.

\section{References}

1. McAllister TW. Neuropsychiatric sequelae of head injuries. Psychiatr Clin North Am. 1992;15(2):395-413.

2. McAllister TW, Flashman LA, Maerlender A, Greenwald RM, Beckwith JG, Tosteson TD, et al. Cognitive effects of one season of head impacts in a cohort of collegiate contact sport athletes. Neurology. 2012;78(22):1777-84.

3. Smith DH, Lowenstein DH, Gennarelli TA, Mclntosh TK. Persistent memory dysfunction is associated with bilateral hippocampal damage following experimental brain injury. Neurosci Lett. 1994;168(1-2):151-4.

4. Dixon CE, Kochanek PM, Yan HQ, Schiding JK, Griffith $R G$, Baum E, et al. One-year study of spatial memory performance, brain morphology, and cholinergic markers after moderate controlled cortical impact in rats. J Neurotrauma. 1999;16(2):109-22.

5. Smith DH, Okiyama K, Thomas MJ, Claussen B, Mclntosh TK. Evaluation of memory dysfunction following experimental brain injury using the Morris water maze. J Neurotrauma. 1991;8(4):259-69.

6. Hicks RR, Smith DH, Lowenstein DH, Saint Marie R, Mclntosh TK. Mild experimental brain injury in the rat induces cognitive deficits associated with regional neuronal loss in the hippocampus. J Neurotrauma. 1993;10(4):405-14.

7. Schmidt RH, Scholten KJ, Maughan PH. Time course for recovery of water maze performance and central cholinergic innervation after fluid percussion injury. J Neurotrauma. 1999;16(12):1139-47.

8. Holsinger T, Steffens DC, Phillips C, Helms MJ, Havlik RJ, Breitner JC, et al. Head injury in early adulthood and the lifetime risk of depression. Arch Gen Psychiatry. 2002;59(1):17-22.

9. Plassman BL, Havlik RJ, Steffens DC, Helms MJ, Newman TN, Drosdick D, et al. Documented head injury in early adulthood and risk of Alzheimer's disease and other dementias. Neurology. 2000;55(8):1158-66.

10. McNaughton N. Cognitive dysfunction resulting from hippocampal hyperactivity - a possible cause of anxiety disorder? Pharmacol Biochem Behav. 1997;56(4):603-11.

11. Sosin DM, Sniezek JE, Waxweiler RJ. Trends in death associated with traumatic brain injury, 1979 through 1992. Success and failure. JAMA. 1995;273(22):1778-80.

12. Jallo J, Loftus CM, editors. Neurotrauma and critical care of the brain. New York: Thieme; 2009.

13. Marion DW. Decompressive craniectomy in diffuse traumatic brain injury. Lancet Neurol. 2011;10(6):497-8.

14. Zhao X, Ahram A, Berman RF, Muizelaar JP, Lyeth BG. Early loss of astrocytes after experimental traumatic brain injury. Glia. 2003;44(2):140-52.

15. Floyd CL, Gorin FA, Lyeth BG. Mechanical strain injury increases intracellular sodium and reverses $\mathrm{Na}+/ \mathrm{Ca} 2+$ exchange in cortical astrocytes. Glia. 2005;51(1):35-46.

16. Ouyang YB, Voloboueva LA, Xu LJ, Giffard RG. Selective dysfunction of hippocampal CA1 astrocytes contributes to delayed neuronal damage after transient forebrain ischemia. J Neurosci. 2007;27(16):4253-60. 
17. Floyd CL, Lyeth BG. Astroglia: important mediators of traumatic brain injury. Prog Brain Res. 2007;161:61-79.

18. Kimelberg HK. Astrocytic edema in CNS trauma. J Neurotrauma. 1992;9(Suppl 1):S71-81.

19. Kimelberg HK, Rutledge E, Goderie S, Charniga C. Astrocytic swelling due to hypotonic or high $\mathrm{K}+$ medium causes inhibition of glutamate and aspartate uptake and increases their release. $\mathrm{J}$ Cereb Blood Flow Metab. 1995;15(3):409-16.

20. Hansson E, Muyderman H, Leonova J, Allansson L, Sinclair $\mathrm{J}$, Blomstrand $\mathrm{F}$, et al. Astroglia and glutamate in physiology and pathology: aspects on glutamate transport, glutamateinduced cell swelling and gap-junction communication. Neurochem Int. 2000;37(2-3):317-29.

21. Nilsson P, Hillered L, Pontén U, Ungerstedt U. Changes in cortical extracellular levels of energy-related metabolites and amino acids following concussive brain injury in rats. J Cereb Blood Flow Metab. 1990;10(5):631-7.

22. Matsushita Y, Shima K, Nawashiro H, Wada K. Realtime monitoring of glutamate following fluid percussion brain injury with hypoxia in the rat. J Neurotrauma. 2000;17(2):143-53.

23. Zhong C, Zhao X, Van KC, Bzdega T, Smyth A, Zhou J, et al. NAAG peptidase inhibitor increases dialysate NAAG and reduces glutamate, aspartate and GABA levels in the dorsal hippocampus following fluid percussion injury in the rat. $J$ Neurochem. 2006;97(4):1015-25.

24. Hinzman JM, Thomas TC, Burmeister JJ, Quintero JE, Huettl P, Pomerleau F, et al. Diffuse brain injury elevates tonic glutamate levels and potassium-evoked glutamate release in discrete brain regions at two days post-injury: an enzyme-based microelectrode array study. J Neurotrauma. 2010;27(5):889-99.

25. Mellergård P, Sjögren F, Hillman J. The cerebral extracellular release of glycerol, glutamate, and FGF2 is increased in older patients following severe traumatic brain injury. $\mathrm{J}$ Neurotrauma. 2012;29(1):112-8.

26. Ashwal S, Holshouser B, Tong K, Serna T, Osterdock $R$, Gross M, et al. Proton MR spectroscopy detected glutamate/glutamine is increased in children with traumatic brain injury. J Neurotrauma. 2004;21(11):1539-52.

27. Zweckberger K, Hackenberg K, Jung CS, Hertle DN, Kiening $\mathrm{KL}$, Unterberg AW, et al. Cerebral metabolism after early decompression craniotomy following controlled cortical impact injury in rats. Neurol Res. 2011;33(8):875-80.

28. Goodman JC, Valadka AB, Gopinath SP, Cormio M, Robertson CS. Lactate and excitatory amino acids measured by microdialysis are decreased by pentobarbital coma in head-injured patients. J Neurotrauma. 1996;13(10):549-56.

29. Palmer AM, Marion DW, Botscheller ML, Bowen DM, DeKosky ST. Increased transmitter amino acid concentration in human ventricular CSF after brain trauma. Neuroreport. 1994;6(1):153-6.

30. Stover JF, Morganti-Kosmann MC, Lenzlinger PM, Stocker R, Kempski OS, Kossmann T. Glutamate and taurine are increased in ventricular cerebrospinal fluid of severely brain-injured patients. J Neurotrauma. 1999;16(2):135-42.

31. Ankarcrona M, Dypbukt JM, Bonfoco E, Zhivotovsky B, Orrenius S, Lipton SA, et al. Glutamate-induced neuronal death: a succession of necrosis or apoptosis depending on mitochondrial function. Neuron. 1995;15(4):961-73.

32. Takahashi M, Billups B, Rossi D, Sarantis M, Hamann M, Attwell D. The role of glutamate transporters in glutamate homeostasis in the brain. J Exp Biol. 1997;200(Pt 2):401-9.

33. Danbolt NC. Glutamate uptake. Prog Neurobiol. 2001;65(1):1-105.
34. Yi JH, Hazell AS. Excitotoxic mechanisms and the role of astrocytic glutamate transporters in traumatic brain injury. Neurochem Int. 2006;48(5):394-403.

35. Choi DW, Rothman SM. The role of glutamate neurotoxicity in hypoxic-ischemic neuronal death. Annu Rev Neurosci. 1990;13:171-82.

36. Palmer AM, Marion DW, Botscheller ML, Swedlow PE, Styren SD, DeKosky ST. Traumatic brain injury-induced excitotoxicity assessed in a controlled cortical impact model. J Neurochem. 1993;61(6):2015-24.

37. Ahmed SM, Weber JT, Liang S, Willoughby KA, Sitterding HA, Rzigalinski BA, et al. NMDA receptor activation contributes to a portion of the decreased mitochondria membrane potential and elevated intracellular free calcium in strain-injured neurons. J Neurotrauma. 2002;19(12):161929.

38. Sun DA, Deshpande LS, Sombati S, Baranova A, Wilson MS, Hamm RJ, et al. Traumatic brain injury causes a longlasting calcium (Ca2+)-plateau of elevated intracellular $\mathrm{Ca}$ levels and altered $\mathrm{Ca} 2+$ homeostatic mechanisms in hippocampal neurons surviving brain injury. Eur J Neurosci. 2008;27(7):1659-72.

39. Zhao X, Gorin FA, Berman RF, Lyeth BG. Differential hippocampal protection when blocking intracellular sodium and calcium entry during traumatic brain injury in rats. $J$ Neurotrauma. 2008;25(10):1195-205.

40. Noble LJ, Hall JJ, Chen S, Chan PH. Morphologic changes in cultured astrocytes after exposure to glutamate. J Neurotrauma. 1992;9(3):255-67.

41. Xiong Y, Zhang Y, Mahmood A, Meng Y, Zhang ZG, Morris $D C$, et al. Neuroprotective and neurorestorative effects of thymosin $\beta 4$ treatment initiated 6 hours after traumatic brain injury in rats. J Neurosurg. 2012;116(5):1081-92.

42. Globus MY, Alonso O, Dietrich WD, Busto R, Ginsberg MD. Glutamate release and free radical production following brain injury: effects of posttraumatic hypothermia. J Neurochem. 1995;65(4):1704-11.

43. Briones TL, Rogozinska M, Woods J. Modulation of ischemia-induced NMDAR1 activation by environmental enrichment decreases oxidative damage. J Neurotrauma. 2011;28(12):2485-92.

44. Pérez-Asensio FJ, Hurtado O, Burguete MC, Moro MA, Salom JB, Lizasoain I, et al. Inhibition of iNOS activity by $1400 \mathrm{~W}$ decreases glutamate release and ameliorates stroke outcome after experimental ischemia. Neurobiol Dis. 2005;18(2):375-84.

45. Brown GC, Neher JJ. Inflammatory neurodegeneration and mechanisms of microglial killing of neurons. Mol Neurobiol. 2010;41(2-3):242-7.

46. Li S, Stys PK. Na(+)-K(+)-ATPase inhibition and depolarization induce glutamate release via reverse $\mathrm{Na}(+)$-dependent transport in spinal cord white matter. Neuroscience. 2001;107(4):675-83.

47. Dutta R, Trapp BD. Mechanisms of neuronal dysfunction and degeneration in multiple sclerosis. Prog Neurobiol. 2011;93(1):1-12.

48. Foster AC, Gill R, Woodruff GN. Neuroprotective effects of MK-801 in vivo: selectivity and evidence for delayed degeneration mediated by NMDA receptor activation. $J$ Neurosci. 1988;8(12):4745-54.

49. Thomas TC, Hinzman JM, Gerhardt GA, Lifshitz J. Hypersensitive glutamate signaling correlates with the development of late-onset behavioral morbidity in diffuse brain-injured circuitry. J Neurotrauma. 2012;29(2):187-200.

50. Kim AH, Kercher GA, Choi DW. Blocking excitotoxicity. In: Marcoux FW, Choi DW, editors. CNS neuroprotection. New York: Springer; 2002. p. 3-36. 
51. Temple MD, O'Leary DM, Faden Al. The role of glutamate receptors in the pathophysiology of traumatic CNS injury. In: Miller LP, Hayes RL. Head trauma: basic, preclinical, and clinical directions. New York: John Wiley and Sons, Inc; 2001. p. 87-113.

52. Campos F, Pérez-Mato M, Agulla J, Blanco M, Barral D, Almeida A, et al. Glutamate excitoxicity is the key molecular mechanism which is influenced by body temperature during the acute phase of brain stroke. PLoS One. 2012;7(8):e44191.

53. Smits M, Houston GC, Dippel DW, Wielopolski PA, Vernooij $\mathrm{MW}$, Koudstaal PJ, et al. Microstructural brain injury in post-concussion syndrome after minor head injury. Neuroradiology. 2011;53(8):553-63.

54. Kotapka MJ, Graham DI, Adams JH, Doyle D, Gennarelli TA. Hippocampal damage in fatal paediatric head injury. Neuropathol Appl Neurobiol. 1993;19(2):128-33.

55. Baldwin SA, Gibson T, Callihan CT, Sullivan PG, Palmer E, Scheff SW. Neuronal cell loss in the CA3 subfield of the hippocampus following cortical contusion utilizing the optical disector method for cell counting. J Neurotrauma. 1997;14(6):385-98.

56. Anderson KJ, Miller KM, Fugaccia I, Scheff SW. Regional distribution of fluoro-jade B staining in the hippocampus following traumatic brain injury. Exp Neurol. 2005;193(1):12530.

57. Gao X, Deng P, Xu ZC, Chen J. Moderate traumatic brain injury causes acute dendritic and synaptic degeneration in the hippocampal dentate gyrus. PLoS One. 2011;6(9):e24566.

58. Mouzon B, Chaytow H, Crynen G, Bachmeier C, Stewart $\mathrm{J}$, Mullan $\mathrm{M}$, et al. Repetitive mild traumatic brain injury in a mouse model produces learning and memory deficits accompanied by histological changes. J Neurotrauma. 2012;29(18):2761-73.

59. Rink A, Fung KM, Trojanowski JQ, Lee VM, Neugebauer E, McIntosh TK. Evidence of apoptotic cell death after experimental traumatic brain injury in the rat. Am J Pathol. 1995;147(6):1575-83.

60. Wang M, Zhang L, Ji X, Yin Y, Xu H, Liu H, et al. Edema and neuronal apoptosis in the hippocampus and cortex of elderly rats following transient cerebral ischemia/reperfusion injury. Neural Regen Res. 2009;4(12):1013-8.

61. Tran LD, Lifshitz J, Witgen BM, Schwarzbach E, Cohen AS, Grady MS. Response of the contralateral hippocampus to lateral fluid percussion brain injury. J Neurotrauma. 2006;23(9):1330-42.

62. Henry LC, Tremblay S, Boulanger Y, Ellemberg D, Lassonde M. Neurometabolic changes in the acute phase after sports concussions correlate with symptom severity. J Neurotrauma. 2010;27(1):65-76.

63. Albensi BC, Sullivan PG, Thompson MB, Scheff SW, Mattson MP. Cyclosporin ameliorates traumatic brain-injuryinduced alterations of hippocampal synaptic plasticity. Exp Neurol. 2000;162(2):385-9.

64. Sanders MJ, Sick TJ, Perez-Pinzon MA, Dietrich WD, Green EJ. Chronic failure in the maintenance of long-term potentiation following fluid percussion injury in the rat. Brain Res. 2000;861(1):69-76.

65. Reeves TM, Lyeth BG, Povlishock JT. Long-term potentiation deficits and excitability changes following traumatic brain injury. Exp Brain Res. 1995;106(2):248-56.

66. Zanier ER, Lee SM, Vespa PM, Giza CC, Hovda DA. Increased hippocampal CA3 vulnerability to low-level kainic acid following lateral fluid percussion injury. J Neurotrauma. 2003;20(5):409-20.

67. Furukawa T, Hoshino S, Kobayashi S, Asakura T, Takahashi M, Atsumi T, et al. The glutamate AMPA receptor antagonist, YM872, attenuates cortical tissue loss, regional cerebral edema, and neurological motor deficits after experimental brain injury in rats. J Neurotrauma. 2003;20(3):269-78.

68. Stewart L, Bullock R, Teasdale GM, Wagstaff A. First observations of the safety and tolerability of a competitive antagonist to the glutamate NMDA receptor (CGS 19755) in patients with severe head injury. J Neurotrauma. 1999;16(9):843-50.

69. Yurkewicz L, Weaver J, Bullock MR, Marshall LF. The effect of the selective NMDA receptor antagonist traxoprodil in the treatment of traumatic brain injury. $J$ Neurotrauma. 2005;22(12):1428-43.

70. McConeghy KW, Hatton J, Hughes L, Cook AM. A review of neuroprotection pharmacology and therapies in patients with acute traumatic brain injury. CNS Drugs. 2012;26(7):613-36.

71. Dhanpani SS, Gupta A, Vivekanandhan S, Sharma BS, Mahapatra BS. Randomized controlled trial of magnesium sulphate in severe closed traumatic brain injury. Indian $\mathrm{J}$ Neurotrauma. 2008;58(1):27-3.

72. Vink $R$, van den Heuvel $C$. Substance $P$ antagonists as a therapeutic approach to improving outcome following traumatic brain injury. Neurotherapeutics. 2010;7(1):74-80.

73. Sen AP, Gulati A. Use of magnesium in traumatic brain injury. Neurotherapeutics. 2010;7(1):91-9.

74. Elliott MB, Tuma RF, Amenta PS, Barbe MF, Jallo JI. Acute effects of a selective cannabinoid-2 receptor agonist on neuroinflammation in a model of traumatic brain injury. $J$ Neurotrauma. 2011;28(6):973-81.

75. Donkin JJ, Cernak I, Blumbergs PC, Vink R. A substance P antagonist reduces axonal injury and improves neurologic outcome when administered up to 12 hours after traumatic brain injury. J Neurotrauma. 2011;28(2):217-24.

76. Büki A, Kövesdi E, Pál J, Czeiter E. Clinical and model research of neurotrauma. Methods Mol Biol. 2009;566:4155.

\section{Correspondence address}

José Luís Alves

Laboratório de Patologia Geral,

Faculdade de Medicina da Universidade de Coimbra

Rua Larga, 3004-5004

Coimbra, Portugal

Telefone +351-239857 777

E-mail: jlmonteiroalves@gmail.com 